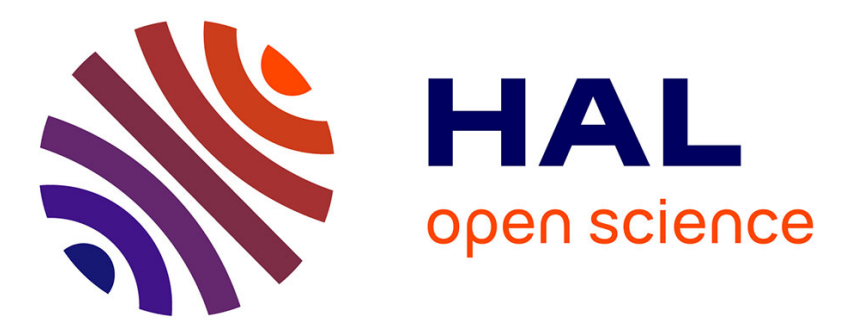

\title{
Breaking C-O Bonds with Uranium: Uranyl Complexes as Selective Catalysts in the Hydrosilylation of Aldehydes
}

Louis Monsigny, Pierre Thuéry, Jean-Claude Berthet, Thibault Cantat

\section{- To cite this version:}

Louis Monsigny, Pierre Thuéry, Jean-Claude Berthet, Thibault Cantat. Breaking C-O Bonds with Uranium: Uranyl Complexes as Selective Catalysts in the Hydrosilylation of Aldehydes. ACS Catalysis, 2019, 9, pp.9025-9033. 10.1021/acscatal.9b01408 . cea-02269575

\section{HAL Id: cea-02269575 https://hal-cea.archives-ouvertes.fr/cea-02269575}

Submitted on 23 Aug 2019

HAL is a multi-disciplinary open access archive for the deposit and dissemination of scientific research documents, whether they are published or not. The documents may come from teaching and research institutions in France or abroad, or from public or private research centers.
L'archive ouverte pluridisciplinaire $\mathbf{H A L}$, est destinée au dépôt et à la diffusion de documents scientifiques de niveau recherche, publiés ou non, émanant des établissements d'enseignement et de recherche français ou étrangers, des laboratoires publics ou privés. 


\title{
Breaking $\mathrm{C}-\mathrm{O}$ Bonds with Uranium: Uranyl Complexes as Selective Catalysts in the Hydrosilylation of Aldehydes
}

\author{
Louis Monsigny, Pierre Thuéry, Jean-Claude Berthet* and Thibault Cantat*.
}

NIMBE, CEA, CNRS, Université Paris-Saclay, CEA Saclay, 91191 Gif-sur-Yvette, France

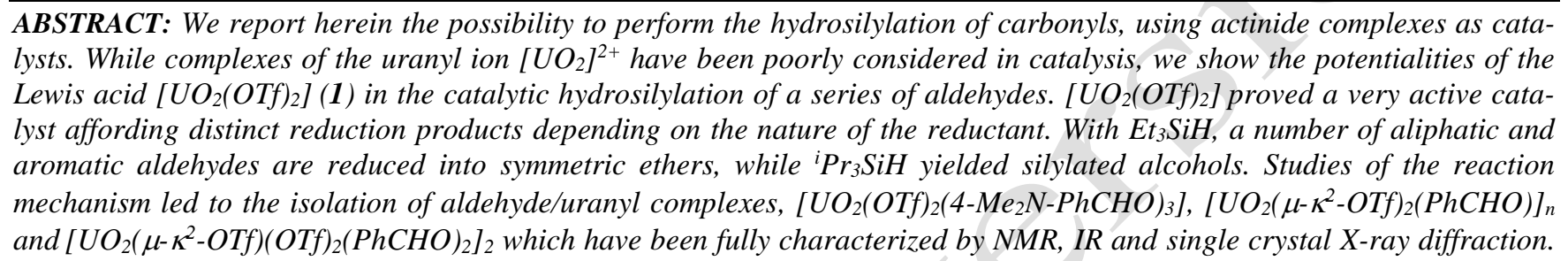

KEYWORDS: Homogenous catalysis, Uranium, Uranyl, Hydrosilylation, Reduction, Aldehydes, Mechanisms.

Actinides have aroused considerable fundamental researches to better understand their fascinating chemical and physical properties. The last decades have witnessed a profuse literature of the chemistry of the 5f-elements revealing unprecedented structures and reactivities including the isolation of new coordination motifs or unusual activation of small molecules (such as $\mathrm{N}_{2}, \mathrm{CO}$ or $\left.\mathrm{CO}_{2}\right) .{ }^{1}$ Translating these chemical features in the realm of catalysis remains shy and catalytic applications have been mainly achieved with the organometallic $\mathrm{An}^{4+}$ species (Th, U) for the hydroamination, hydrosilylation and polymerization of alkenes and alkynes. ${ }^{1 \mathrm{~b}, 2}$ The transformation of oxygenated compounds with actinide catalysts represents a difficult task, as the strength of actinide-oxygen bonds may preclude efficient catalytic turnover. ${ }^{1 \mathrm{~d}, 3}$ Nonetheless, the group of Eisen recently challenged this vision by unveiling the ability of some uranium(IV) and thorium(IV) complexes to promote the catalytic dimerization of aldehydes (Tishchenko reaction). ${ }^{4}$ These authors thus paved the way to developments in this field, substantiated by the subsequent reports of key examples of hydroalkoxylation, ${ }^{5}$ addition of alcohols on heterocumulene, ${ }^{6}$ ring opening polymerization of epoxides $^{7}$ and esters ${ }^{8}$ and dehydration of amides. ${ }^{9}$

The reduction of oxygenated substrates, involving the cleavage of $\mathrm{C}-\mathrm{O}$ and/or $\mathrm{C}=\mathrm{O}$ bonds, is of fundamental importance, for instance in the conversion of carbonyl or bio-based substrates ${ }^{10}$ and $\mathrm{CO}_{2}{ }^{11}$ The utilization of actinide based catalysts in this area is extremely rare, as the metal ion must cope with the strength of the An-O bonds and tolerate the reductant. ${ }^{12}$ Eisen et al. showed that aldehydes could undergo esterification reactions in the presence of alcohols, in the presence of $\alpha, \alpha, \alpha$,trifluoro-benzophenone as a sacrificial hydride acceptor (Erreur! Source du renvoi introuvable., A). ${ }^{13}$ In this example, the thorium(IV) complex favors a hydrogen transfer that formally results in the reduction of $\alpha, \alpha, \alpha$,trifluoro-benzophenone. Very recently the same group reported the first catalytic reduction of carbonyl compounds (aldehydes and ketones) with hydroboranes $\left(\mathrm{R}_{2} \mathrm{BH}\right)$, in the presence of thorium complexes able to generate reactive [Th]-H species as catalytically active intermediates, thereby unlocking new opportunities in catalysis with actinides (Erreur ! Source du renvoi introuvable., $B) .{ }^{12 a}$

In contrast to hydroboranes, hydrosilanes $\left(\mathrm{R}_{3} \mathrm{SiH}\right)$ have never been used for the reduction of carbonyl or heterocumulene compounds with actinide catalysts. Hydrosilanes are milder reductants compared to hydroboranes ${ }^{14}$ or diboranes ${ }^{15}$. Yet, the slight polarization of the Si-H bond offers appealing advantages for the development of selective reduction processes in organic chemistry, ${ }^{10,11}$ the valorization of biomass, ${ }^{16}$ and the recycling of plastics. ${ }^{17}$

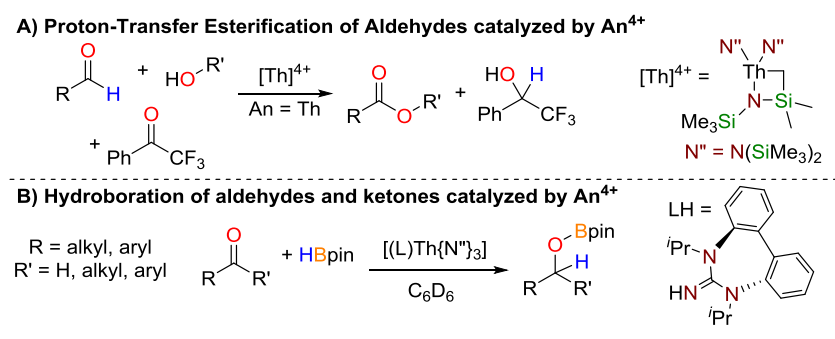

C) This work: hydrosilylation of aldehydes catalyzed by $\mathrm{UO}_{2}^{2+}$

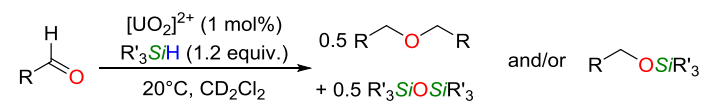

Scheme 1. Exhaustive overview of the catalytic reduction of oxygenated compounds using actinide complexes.

These recent successes in catalytic reduction chemistry have been achieved with $\mathrm{An}^{4+}(\mathrm{An}=\mathrm{U}, \mathrm{Th})$ organometallic complexes, and the catalysts are in consequence sensitive to air and moisture. In contrast, the uranyl cation $\left[\mathrm{UO}_{2}\right]^{2+}$ is the most abundant form of uranium in the environment and it is ubiquitous in the nuclear industry. Although the use of uranyl in reductive transformations would be novel and attractive, it also poses significant questions: 
indeed, a handful of reports describe the reduction of $\left[\mathrm{UO}_{2}\right]^{2+}$ species into $\mathrm{U}(\mathrm{V})$ or $\mathrm{U}(\mathrm{IV})$ compounds by hydrosilanes in the

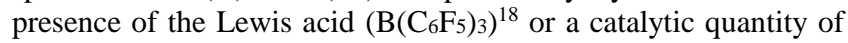
bases $\left(\mathrm{MX}=\mathrm{KNSiMe}_{3}, \mathrm{KO}^{t} \mathrm{Bu}\right.$, etc $) .{ }^{15 \mathrm{a}}$ These findings prompted us to investigate, in anhydrous conditions, the potentialities of uranyl species as catalysts in the reductive hydrosilylation of carbonyls.

The reduction of benzaldehyde (2) with a uranyl catalyst and a hydrosilane was initially investigated as a model reaction (Eqn (1)). Because $\left[\left\{\mathrm{UO}_{2} \mathrm{Cl}_{2}(\mathrm{THF})\right\}_{2}\right]_{2}$ is an efficient precatalyst for the ring opening polymerization of epoxides, ${ }^{7}$ it was first tested with a $2.5 \mathrm{~mol} \%$ charge for the hydrosilylation of 2 with 1.2 equivalent of triethylsilane $\left(\mathrm{Et}_{3} \mathrm{SiH}\right)$, at room temperature in dichloromethane (Table 1, entry 1). Poorly soluble in dichloromethane, the dimeric complex dissolved upon addition of excess $\mathbf{2}$ to give a clear yellow solution, but proved inactive. In similar conditions, the iodide analogue $\left[\left\{\mathrm{UO}_{2} \mathrm{I}_{2}(\mathrm{THF})\right\}_{3}\right](5 \mathrm{~mol} \%)$ displayed a weak activity with a low conversion of 2 into the symmetric ether $\mathrm{PhCH}_{2} \mathrm{OCH}_{2} \mathrm{Ph}$ (2a), obtained in ca 23\% yield within $19 \mathrm{~h}$ (Table 1, entry 2).

Such reductive etherification of aldehyde has been reported with various Lewis acid such as $\mathrm{Me}_{3} \mathrm{SiX}\left(\mathrm{X}=\mathrm{I}^{19}\right.$, OTf), $\mathrm{Fe}(\mathrm{III})^{20}, \mathrm{M}(\mathrm{OTf})_{3}\left(\mathrm{M}=\mathrm{In}^{21}, \mathrm{Sc}, \mathrm{Bi}, \mathrm{Ga}, \mathrm{Al}^{22}\right), \mathrm{M}(\mathrm{OTf})_{2}(\mathrm{M}=$ $\left.\mathrm{Cu}^{23}, \mathrm{Zn}^{24}\right)$ as well as several $\mathrm{Sb}(\mathrm{III})^{25}$ and $\mathrm{Sb}(\mathrm{V})^{26}$ compounds. ${ }^{27}$ Several reports describe the reductive coupling of aldehydes and ketones to ethers with organosilicon reagents in the presence of Lewis acid activators.

The high Lewis acidity of metal triflates has been extensively used in recent years in a number of organic transformations since they enhance reactivity of substrates through electrophilic activation. ${ }^{28}$ Accordingly, we tested a stronger Lewis acid, e.g. uranyl triflate $\left[\mathrm{UO}_{2}(\mathrm{OTf})_{2}\right](\mathbf{1})$, in the hydrosilylation of 2. Yellow complex $\mathbf{1}$ is quite soluble in polar organic solvents, such as THF (which undergoes rapid polymerization), pyridine and acetonitrile, but is insoluble in toluene and dichloromethane. Addition of 1.2 equiv. $\mathrm{Et}_{3} \mathrm{SiH}$ to a slurry of complex 1 in toluene or $\mathrm{CH}_{2} \mathrm{Cl}_{2}$ did not induce solubilization of $\mathbf{1}$ or its reaction at 20 or $65^{\circ} \mathrm{C}$. However, addition of benzaldehyde (2) to $1 \mathrm{~mol} \%$ of catalyst $\mathbf{1}$ at room temperature led to an immediate clear yellow solution. ${ }^{1} \mathrm{H}$ NMR monitoring of the reaction showed the quantitative conversion of benzaldehyde, within 1 hour, into ether $\mathbf{2 a}$ and the siloxane $\mathrm{Et}_{3} \mathrm{SiOSiEt}_{3}$ (Table 1, entry 3). Interestingly, a somewhat different outcome was observed when an excess $\mathrm{Et}_{3} \mathrm{SiH}$ (> 4 equiv.) was used, since ether 2a along with the silylated alcohol $\mathrm{PhCH}_{2} \mathrm{OSiEt}_{3}$ (2b) were formed in a $\sim 75: 25$ ratio (Table 1 , entry 4 ).

To probe the influence of the nature of the hydrosilane on the reduction of $\mathbf{2}$, different reagents were used. Phenyldimethylsilane $\left(\mathrm{PhMe}_{2} \mathrm{SiH}\right)$ and triphenylsilane $\left(\mathrm{Ph}_{3} \mathrm{SiH}\right)$ behaved similarly to $\mathrm{Et}_{3} \mathrm{SiH}$ affording $\mathbf{2 a}$ quantitatively, although a longer reaction time ( $6 \mathrm{~h}$ ) was necessary with $\mathrm{Ph}_{3} \mathrm{SiH}$ (Table 1 , entries 5 and 6). The use of the sterically hindered ${ }^{i} \mathrm{Pr}_{3} \mathrm{SiH}$ induced a considerable change with the selective formation of the silylated alcohol $\mathrm{PhCH}_{2} \mathrm{OSi}^{i} \mathrm{Pr}_{3}(2 \mathrm{c})$ in nearly quantitative yield within $12 \mathrm{~h}$ (Table 1 , entry 7 ).

The reductive etherification of aldehydes proved general and a number of benzaldehyde derivatives were successfully transformed into the corresponding dibenzylethers 3-10 in excellent yields, ranging from 83 to $99 \%$ (

). Depending on the nature of the substituents, the reactions required $0.5-10 \mathrm{~h}$ at room temperature to go to completion, with the release of $\mathrm{Et}_{3} \mathrm{SiOSiEt}_{3}$ as by-product. More precisely, $p$ substituted benzaldehydes 3-7, featuring electron withdrawing $(\mathrm{EW})$ halogen atoms $(\mathrm{Cl}, \mathrm{Br}, \mathrm{I})$ or electron donating alkyl (ED) groups $\left(\mathrm{Me},{ }^{\mathrm{t}} \mathrm{Bu}\right)$ were readily reduced into the symmetrical ethers 3a-7a (

). Surprisingly, the increased steric congestion in 9 - possessing an ortho-methyl group - or in the anthracene derivative $\mathbf{8}$ did not affect the rate of the reaction. Importantly, ketone groups were tolerated and the hydrosilylation of 4acetylbenzaldehdye $\mathbf{1 0}$ led chemoselectively to ether 10a with excellent yields and a longer reaction time $(10 \mathrm{~h})$. This selectivity was confirmed with the absence of reaction with ketones (acetophenone or benzophenone). Furthermore, the carboxylic functionality in ortho position of $\mathbf{1 1}$ was maintained upon hydrosilylation of the formyl moiety with 2.4 equiv. of $\mathrm{Et}_{3} \mathrm{SiH}$ and $1 \mathrm{~mol} \%$ of uranyl $\mathbf{1}$, and it led to an intramolecular cyclization to phthalide 11a. Benzaldehyde derivatives with EW para-substituents $\left(\mathrm{CN}\right.$ or $\left.\mathrm{NO}_{2}\right)$ afforded, after long reaction times (12 and $24 \mathrm{~h}$, respectively), a 1:1 mixture of ether 12a and silyl ether $\mathbf{1 2 b}$ or only the silylated alcohol $\mathbf{1 3 b}$, respectively. While no reaction was observed with $p$ dimethylaminobenzaldehyde (15), $p$-methoxybenzaldehyde led to a complex mixture of deoxygenated and Friedel-Craft products. Pyridine-, furan-, and thiophene-2-carboxaldehyde derivatives were also found unreactive, a trend that may be related to a deleterious chelation of the catalyst by the substrate.

Table 1: Optimization of the hydrosilylation of benzaldehyde (2), catalyzed by uranyl(VI) complexes

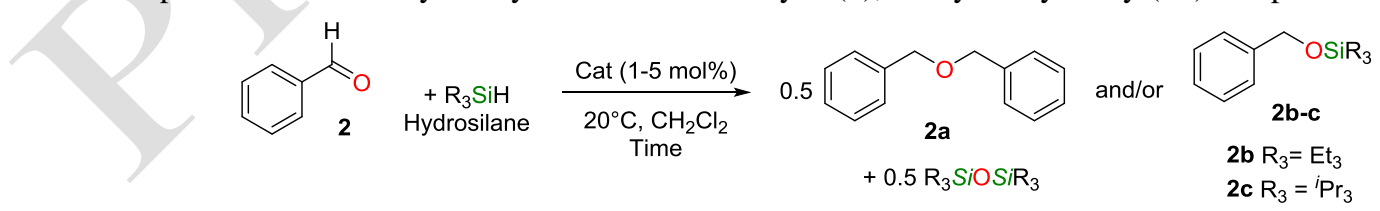

\begin{tabular}{|c|c|c|c|c|c|c|}
\hline Entry & Cat (mol\%) & Hydrosilane (n eq.) & Time & Conversion (\%) & 2a (\%) & 2b-c (\%) \\
\hline $\mathbf{1}$ & {$\left[\left\{\mathrm{UO}_{2} \mathrm{Cl}_{2}(\mathrm{THF})\right\}_{2}\right](5)$} & $\mathrm{Et}_{3} \mathrm{SiH}(1.2)$ & $24 \mathrm{~h}$ & $<5 \%$ & - & - \\
\hline $\mathbf{2}$ & {$\left[\left\{\mathrm{UO}_{2} \mathrm{I}_{2}(\mathrm{THF})\right\}_{3}\right](5)$} & $\mathrm{Et} 3 \mathrm{SiH}(1.2)$ & $19 \mathrm{~h}$ & $39 \%$ & $23 \%$ & $13 \%$ \\
\hline $\mathbf{3}$ & {$\left[\mathrm{UO}_{2}(\mathrm{OTf})_{2}\right] \mathbf{1}(1)$} & $\mathrm{Et}_{3} \mathrm{SiH}(1.2)$ & $1 \mathrm{~h}$ & $>99 \%$ & $>99 \%$ & - \\
\hline $\mathbf{4}$ & $\mathbf{1}(1)$ & $\mathrm{Et}_{3} \mathrm{SiH}(4)$ & $1 \mathrm{~h}$ & $>99 \%$ & $73 \%$ & $24 \%$ \\
\hline $\mathbf{5}$ & $\mathbf{1}(1)$ & $\mathrm{PhMe} 2 \mathrm{SiH}(1.2)$ & $1 \mathrm{~h}$ & $>99 \%$ & $>99 \%$ & - \\
\hline
\end{tabular}




\begin{tabular}{|c|c|c|c|c|c|c|}
\hline $\mathbf{6}$ & $\mathbf{1}(1)$ & $\mathrm{Ph}_{3} \mathrm{SiH}(1.2)$ & $6 \mathrm{~h}$ & $>99 \%$ & $>99 \%$ & - \\
\hline $\mathbf{7}$ & $\mathbf{1}(1)$ & $\mathrm{Pr} \mathrm{PriH}_{3}(1.2)$ & $12 \mathrm{~h}$ & $>99 \%$ & $\mathbf{2 c}>99 \%$ \\
\hline $\mathbf{8}$ & - & $\mathrm{Et}{ }_{3} \mathrm{SiH}(1.2)$ & $24 \mathrm{~h}$ & $0 \%$ & - \\
\hline
\end{tabular}

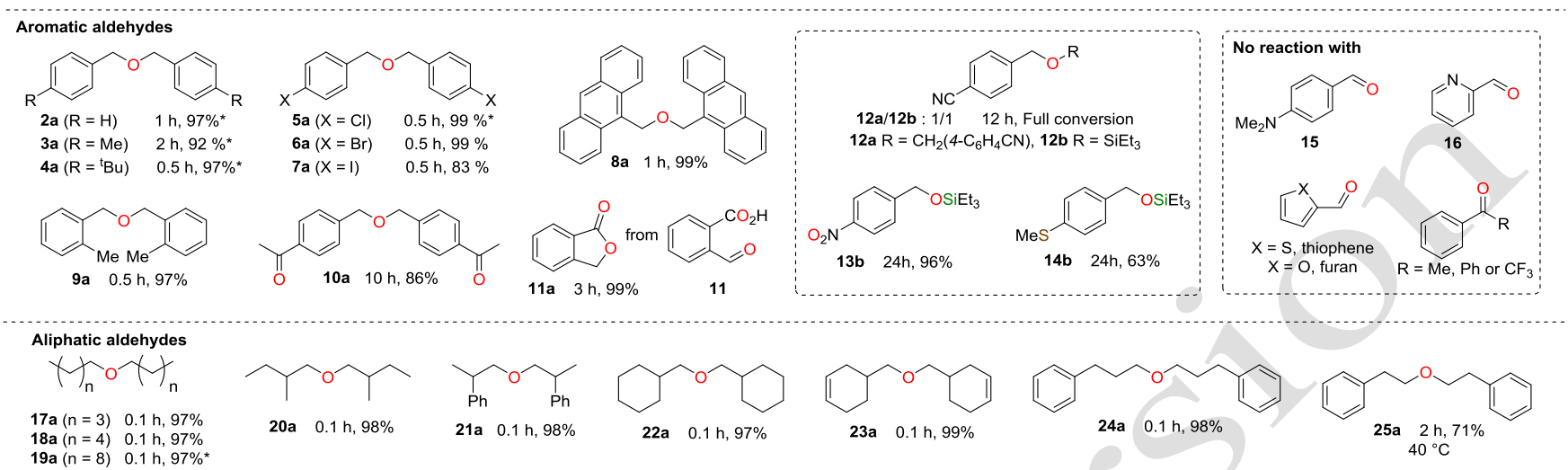

Scheme 2. Scope of the catalytic reductive etherification of aromatic and aliphatic aldehydes with $\mathrm{Et}_{3} \mathrm{SiH}_{\mathrm{and}}\left[\mathrm{UO}_{2}(\mathrm{OTf})_{2}\right](\mathbf{1})$. Reaction conditions: aldehyde $(0.2 \mathrm{mmol}) ; 0.24 \mathrm{mmol} \mathrm{Et} 3 \mathrm{SiH} ; \mathrm{CD}_{2} \mathrm{Cl}_{2}(0.4 \mathrm{~mL} ; 0.5 \mathrm{M})$. Yields determined by ${ }^{1} \mathrm{H} \mathrm{NMR}$ using mesitylene $(10 \mathrm{~mL})$ as an internal standard. *Yields of isolated products from scaled-up experiments ( $2 \mathrm{mmol}$ scale).

The divergent selectivities in these reactions can be tentatively explained by considering the Hammett $\sigma$ parameters of the substituents. ${ }^{29}$ (Scheme 3) For strong ED groups, characterized by negative $\sigma$ constants $\left(\mathrm{NMe}_{2},-0.83\right)$, no reaction occurs. The formation of symmetric ethers is favored for $\sigma$ constants in the range -0.3 to 0.5 . More electron deficient substrates, characterized by higher $\sigma$ constants, require longer reaction times and exhibit a different selectivity, with the formation of silylated alcohols $\mathrm{ArCH}_{2} \mathrm{OSiR}_{3}$ being facilitated.

The behavior of the $p$-MeS-benzaldehyde $\left(\sigma_{p a-}\right.$ $r a(S M e)=\sigma(H)=0.00)$ is intriguing. Instead of the expected dibenzylether derivative 14a, only 14b was obtained, albeit with a low $63 \%$ yield, after $24 \mathrm{~h}$. This result may suggest a peculiar influence of sulfur although thioethers are weak ligands for the hard uranium(VI) ion.

The formation of ethers $\mathrm{RCH}_{2} \mathrm{OCH}_{2} \mathrm{R}$ or silylethers $\mathrm{RCH}_{2} \mathrm{OSiR}_{3}$ from aromatic and aliphatic aldehydes has been previously reported with $\mathrm{Zn}(\mathrm{OTf})_{2}$ in the presence of TMDS (TMDS = tetramethyldisiloxane) or $\mathrm{Et}_{3} \mathrm{SiH}$, and the selectivity strongly correlated to the electron-donating or electronwithdrawing properties of the aldehyde substituents. ${ }^{24}$ Similar results have been observed with $\mathrm{Cu}(\mathrm{OTf})_{2}$ and this catalyst was also able to reduce ketones into the corresponding symmetrical ether and carboxylic acids into the corresponding alcohols. ${ }^{23}$ Altogether, these observations may suggest that the uranyl cation can follow catalytic paths similar to Lewis acids based on the transition metals.

In the presence of Lewis acidic complexes, a common side reaction of aliphatic aldehydes is the homo-aldol condensation, relying on the keto-enol tautomerism catalyzed by Lewis acids such as lanthanide triflates. ${ }^{28 a}, 30$ Gratifyingly, in the conditions of eqn. 2, the aliphatic aldehydes 17-24 were rapidly converted into the corresponding ethers 17a-24a in excellent yields ( $97-99 \%$ in $0.1 \mathrm{~h}$ ) without any side-product observed. Aldol condensation only occurred at elevated tempera- ture $\left(>70^{\circ} \mathrm{C}\right)$ with longer reaction time $(>2 \mathrm{~h}$, see SI). Linear aldehydes 17-19 as well as branched aliphatic aldehydes 20-22 displayed a similar reactivity with respect to the uranyl catalyzed hydrosilylation. It is noteworthy that the double bond in cyclohexene $\mathbf{2 3}$ was left untouched. $\alpha, \beta$-unsaturated aldehydes

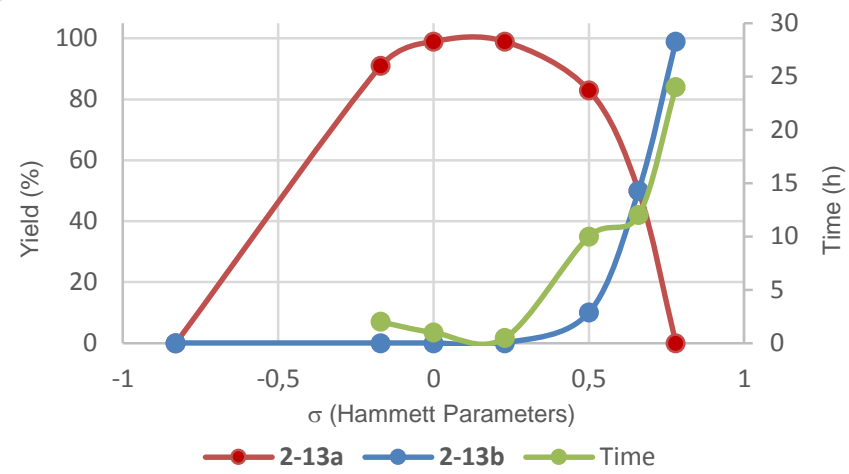

Scheme 3. Correlation of the yields of ethers 2-13a (red line) and silylated alcohols $\mathbf{2 - 1 3 b}$ (blue line) and reaction time (green line) of the reaction of hydrosilylation of aldehydes 4$\mathrm{R}-\mathrm{PhCHO}\left(\mathrm{R}=\mathrm{NMe}_{2}, \mathrm{Me}, \mathrm{H}, \mathrm{Cl}, \mathrm{MeC}(\mathrm{O}), \mathrm{CN}, \mathrm{NO}_{2}\right)$ with the Hammett parameters

led to a rapid degradation of the starting materials as observed with 1-cyclohexene-1-carboxaldehyde and cinnamaldehyde. In contrast, hydrocinnamaldehyde was efficiently reduced to $\mathbf{2 4 a}$ at room temperature, while the reductive etherification of phenylacetaldehyde (25) required a longer reaction time and a smooth heating to $40{ }^{\circ} \mathrm{C}$. ${ }^{1} \mathrm{H}$ and ${ }^{13} \mathrm{C}$ NMR monitoring of the later catalytic run showed well separated resonances assignable to free aldehyde $\mathbf{2 5}$ and its trimeric form $\left(\mathrm{PhCH}_{2} \mathrm{CHO}\right)_{3}$ which are in equilibrium $\left(\mathrm{K}\left(20^{\circ} \mathrm{C}\right)=0.77\right.$, Eqn. 3, Scheme 4). Formation of the trioxane is catalyzed by 
uranyl 1, as observed in a subsequent experiment by mixing only uranyl triflate and $\mathbf{2 5}$ in $\mathrm{CD}_{2} \mathrm{Cl}_{2}$. While the trioxane is favored at low temperatures, moderate heating at $40{ }^{\circ} \mathrm{C}$ gave back the genuine aldehyde $\mathbf{2 5}$ which can then be reduced into the ether 25a.

The thermodynamic parameters measured for the equilibrium depicted in eqn. (3) revealed an exothermic $(\Delta \mathrm{H}=-54 \pm 0.3$ $\mathrm{kJ} / \mathrm{mol})$ and entropically unfavorable reaction $(\Delta \mathrm{S}=-184.6 \pm 1.2$ $\mathrm{J} / \mathrm{K} . \mathrm{mol}$ ) with an overall reaction free energy of $\Delta \mathrm{G}=+84.2 \mathrm{~J} / \mathrm{mol}$ at $20{ }^{\circ} \mathrm{C}$ (see SI). The cyclotrimerisation of $\mathbf{2 5}$ is reminiscent of the cyclisation of methanal $\left(\mathrm{CH}_{2} \mathrm{O}\right)$ to 1,3,5-trioxane. Such a reactivity has been widely reported with different Lewis acids (incl. $\mathrm{Ru},{ }^{31} \mathrm{Me}_{3} \mathrm{SiCl},{ }^{32} \mathrm{InCl}_{3},{ }^{33} \mathrm{FeCl}_{3},{ }^{34} \mathrm{etc}^{35}$ ). If the other aldehydes with $\alpha$-hydrogen atoms are left untouched by $\mathbf{1}$ in $\mathrm{CH}_{2} \mathrm{Cl}_{2}$, in neat condition they were transformed into the corresponding 1,3,5-trioxanes which often solidified in the flask.

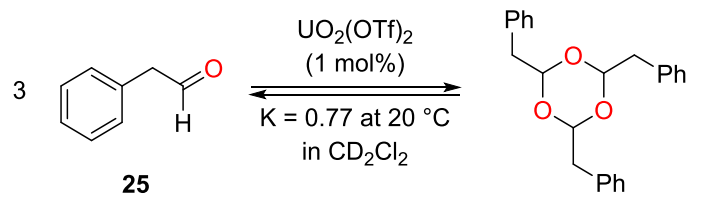

Scheme 4: Equilibrium reaction between phenylacetaldehyde and its trioxane form catalyzed by uranyl complex $\mathbf{1}$ in $\mathrm{CD}_{2} \mathrm{Cl}_{2}$

Thus, in presence of uranyl catalyst $\mathbf{1}$, the aldehydes 21, 22, $\mathbf{2 4}, \mathbf{2 5}$, rapidly stiffened as white solid trimers within $10 \mathrm{~min}$ 30 min while compounds 17, 18 gave colorless oils. These trioxanes have been readily isolated in quantitative yields (see SI).

Replacing $\mathrm{Et}_{3} \mathrm{SiH}$ with ${ }^{\mathrm{i}} \mathrm{Pr}_{3} \mathrm{SiH}$ considerably altered the course of the reaction and aromatic and aliphatic aldehydes were transformed into the corresponding silylated alcohols (Eqn (4)). The reaction required $12 \mathrm{~h}$ to reach completion in $\mathrm{CH}_{2} \mathrm{Cl}_{2}$, and showed quantitative conversions, excellent selectivity and yields (92-98\%) (Scheme 5).

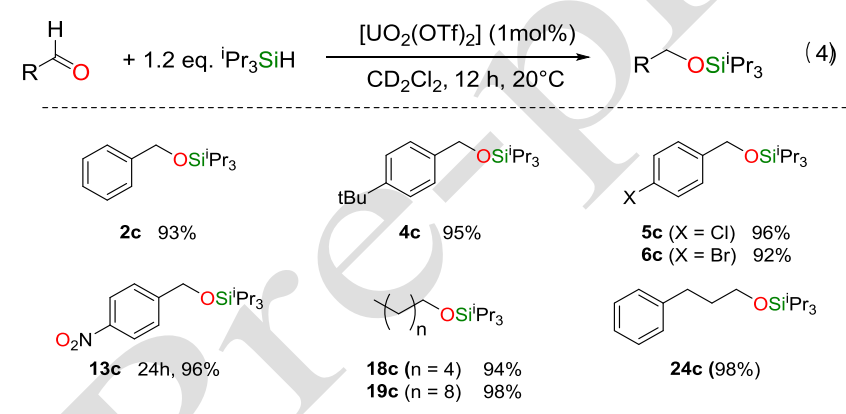

Scheme 5. Reduction of aldehydes into silylated alcohols catalyzed by $\left[\mathrm{UO}_{2}(\mathrm{OTf})_{2}\right]$ in presence of ${ }^{\mathrm{i}} \mathrm{Pr}_{3} \mathrm{SiH}$.Quantitative conversion for all the reactions. Yields determined by ${ }^{1} \mathrm{H}$ NMR using mesitylene $(10 \mu \mathrm{L})$ as internal standard.

In order to gain insights into the mechanism of this reaction and to better apprehend the role of the uranyl catalyst, kinetic measurements were carried out by ${ }^{1} \mathrm{H}$ NMR for the reductive coupling of $p$-MePhCHO with $\mathrm{Et}_{3} \mathrm{SiH}$ (see ESI for details). These investigations revealed a complex rate law for the reaction presented in Eqn. 5. with a third order for the catalyst, a first order in hydrosilane and an inverse $3 / 2$ order in aldehyde.

$$
\frac{\partial p}{\partial t}=\mathrm{k} \times \frac{[\mathbf{1}]^{3} \times[\text { hydrosilane }]^{1}}{[\text { aldehyde }]^{3 / 2}}
$$

The activation energy $(\mathrm{Ea})$, the enthalpy $\left(\Delta \mathrm{H}^{\ddagger}\right)$, and the entropy $\left(\Delta \mathrm{S}^{\ddagger}\right)$ of activation for the rate-determining step were found to be $11.4 \pm 0.40 \mathrm{kcal} / \mathrm{mol}, 10.8 \pm 0.5 \mathrm{kcal} / \mathrm{mol}$, and $43.2 \pm 0.5 \mathrm{eu}$, respectively. $\left(\Delta \mathrm{G}^{\ddagger}=23.7 \pm 0.6 \mathrm{kcal} / \mathrm{mol}\right)$. The high negative entropy values would indicate a highly ordered transition state at the rate-determining step (RDS). Studies of the isotopic effect by using deuterated hydrosilanes yielded a KIE value of $2.3 \pm 0.1$, revealing that the $\mathrm{H}$ atom transfer was involved in the RDS. A secondary kinetic isotope effect (SDKIE) of 0.90 was determined for $\mathrm{Et}_{3} \mathrm{SiH}$ with the deuterated substrate PhCDO. This low value $(<1)$ is indicative of a purely ionic mechanism, excluding a radical pathway. ${ }^{36}$

The inverse kinetic order observed for the aldehyde underlines a progressive deactivation of the catalyst with increasing concentrations of aldehyde, likely by saturation of the coordination sphere of uranium which may impede an access to the metal center for the reductant or a decreased Lewis acidity on the $\mathrm{U}^{\mathrm{VI}}$ cation. Such interpretation is supported by the acceleration noted in the hydrosilylation of bulky aldehydes derivatives $\left(0.5 \mathrm{~h}\right.$ for $p$ - ${ }^{\mathrm{B}} \mathrm{Bu}$ or $o$-Me-compounds 4 and $9 v s 2 \mathrm{~h}$ for $p$ $\mathrm{MePhCHO}(3)$ ), which may favor the occurrence of unsaturated uranium centers. Influence of the triflate ion is also notable. Thus addition of 1 eq. $\left[{ }^{n} \mathrm{Bu}_{4} \mathrm{~N}\right] \mathrm{OTf}$ proved deleterious with a dramatic decrease of the rate of the reaction which is reflected by a kinetic constant $\mathrm{k}_{\mathrm{obs}}$ of $6.0 .10^{-6} \mathrm{M}^{-\mathrm{s}^{-1}}$ while it is $2.5 .10^{-}$ ${ }^{5} \mathrm{M} . \mathrm{s}^{-1}$ without $\left[{ }^{n} \mathrm{Bu}_{4} \mathrm{~N}\right] \mathrm{OTf}$.

In order to better apprehend the mechanism of Eqns 2 and 4, we turned our attention on the uranium species that might be formed when complex $\mathbf{1}$ is treated with either hydrosilanes or aldehydes, or under the catalytic conditions.

The insolubility of [ $\left.\mathrm{UO}_{2}(\mathrm{OTf})_{2}\right]$ in $\mathrm{CD}_{2} \mathrm{Cl}_{2}$ disfavors the observation by ${ }^{1} \mathrm{H}$ NMR of a possible contact between $\mathrm{Et}_{3} \mathrm{SiH}$ and the amphoteric uranyl complex. ${ }^{37}$ However, when suspended in neat $\mathrm{PhSiH}_{3}$, a stronger reductant than $\mathrm{Et}_{3} \mathrm{SiH}$, the yellow powder of $\mathbf{1}$ turned green after $1 \mathrm{~h}$ at $100^{\circ} \mathrm{C}$. Addition of pyridine gave an immediate orange solution upon which slow addition of pentane afforded green crystals of the hexanuclear U(IV) oxide cluster $\left[\mathrm{U}_{6} \mathrm{O}_{8}(\mathrm{OTf})_{8}(\mathrm{py})_{10}\right]$ previously obtained from reduction of uranyl. ${ }^{38}$ The reduction of $\mathbf{1}$ into uranium(IV) is reminiscent of the instability of uranyl borohydride compounds, which likely results from $\mathrm{H}_{2}$ loss from putative uranyl hydride intermediates. ${ }^{39}$

While complexation of uranium ions with ketones has given rise to numerous studies related to nuclear fuel reprocessing, similar investigations with aldehydes are rare. Only two species, e.g. the uranyl(VI) $\left[\mathrm{UO}_{2}\left(\kappa^{2}-\mathrm{CSAL}\right)\left(\kappa^{1}-\mathrm{CSAL}\right)(\mathrm{DMSO})_{2}\right]$ $(\mathrm{CSAL}-\mathrm{H}=\text { 3,5-dichloro-2-hydroxybenzaldehyde })^{40}$ and $\left[\mathrm{UO}_{2}\left(\kappa^{2}-\mathrm{ALAC}\right)_{2}\left(\mathrm{H}_{2} \mathrm{O}\right)\right] \quad(\mathrm{ALAC}-\mathrm{H}=$ 2-dimethylacetal-4chloro-2-hydroxybenzaldehyde) compounds have been crystallographically characterized. ${ }^{41}$ It is noteworthy that the ALAC and CSAL ligands are derivatives of salicylaldehyde (2-hydroxybenzaldehyde), for which the coordination of the formyl moiety to uranium is facilitated by a chelation effect ensured by bonding of the phenoxide group.

In presence of a series of aldehydes reported in

, suspension of $\mathbf{1}$ in $\mathrm{CH}_{2} \mathrm{Cl}_{2}$ immediately gave clear yellow to orange solutions. Most attempts at crystallization failed, but crystals suitable for X-ray diffraction were grown with ben- 
zaldehyde (2) and $p-\mathrm{Me}_{2} \mathrm{NPhCHO}$ (16), by slow diffusion of pentane into a $\mathrm{CH}_{2} \mathrm{Cl}_{2}$ solution of $\mathbf{1}$ with a large excess of ligand.

Yellow crystals of the polymer $\left[\mathrm{UO}_{2}\left(\mu-\kappa^{2}-\mathrm{OTf}\right)_{2}(\mathrm{PhCHO})\right]_{\mathrm{n}}$ (26) (Figure 1) and the dimer $\left[\mathrm{UO}_{2}\left(\mu-\kappa^{2}-\mathrm{OTf}\right)\left(\kappa^{1}-\right.\right.$ OTf) $\left.(\mathrm{PhCHO})_{2}\right]_{2}$ (27) (Figure 2 and 3 ) were obtained from distinct batches prepared under the same conditions. ${ }^{42}$ Attempts at isolation of powdery samples of the uranyl(VI) compound, by precipitation from a mixture of 1 with 10 equiv. of 2, gave a dry product formulated as $\left[\mathrm{UO}_{2}(\mathrm{OTf})_{2}(\mathrm{PhCHO})_{2}\right]$ (according to NMR and elemental analyses) in $74 \%$ yield. The ${ }^{1} \mathrm{H}$ NMR spectra in $\mathrm{CH}_{2} \mathrm{Cl}_{2}-d_{2}$ revealed a thin $\mathrm{CHO}$ signal at $\delta=10.1$ slightly shifted downfield in comparison with that of free benzaldehyde 2 (10.0 ppm).

With $p-\mathrm{Me}_{2} \mathrm{NPhCHO}$, dark-orange crystals of the monometallic complex $\left[\mathrm{UO}_{2}\left(\kappa^{1}-\mathrm{OTf}\right)_{2}\left(\mathrm{Me}_{2} \mathrm{~N}-\mathrm{PhCHO}\right)_{3}\right]$ (28) were readily collected (Figure 3 ). Dried powder samples have the same formula and displayed a ${ }^{1} \mathrm{H}$ NMR signal at $\delta=10.31$ for the $\mathrm{CHO}$ group and a singlet at $\delta=3.24$ for the $\mathrm{Me}_{2} \mathrm{~N}$ group (vs $\delta=9.70$ and $\delta=3.07$ for the free aldehyde 15).

The three structures evidence that the aldehydes are weak ligands for the $\left[\mathrm{UO}_{2}\right]^{2+}$ ion as triflate bridges are sometimes maintained and not displaced towards the formation of cationic species as in $\left[\mathrm{UO}_{2}\left(\mathrm{OPPh}_{3}\right)_{4}\right][\mathrm{OTf}]_{2}{ }^{43}$ Moreover, the monomeric form of $\mathbf{2 8}$ confirms the stronger coordinating ability of the more electron rich $p$ - $\mathrm{Me}_{2} \mathrm{NPhCHO}$, compared to benzaldehyde.

Complexes 26 and 27 both display an inversion center located at the center of the $\mathrm{U}_{2} \mathrm{~S}_{2}$ square entity. The three complexes display the usual pentagonal-bipyramidal uranium coordination environment with the equatorial plane, defined by the uranium atom and five oxygen

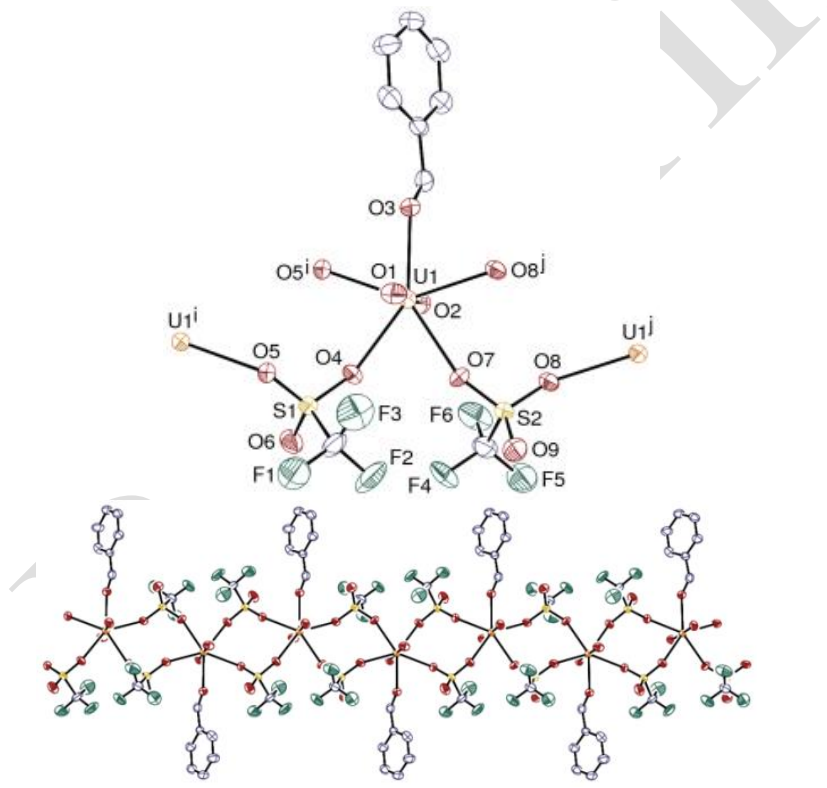

Figure. 1 Views of complex $\mathbf{2 6}$ with $50 \%$ probability displacement ellipsoids. Hydrogen atoms are omitted for clarity. Symmetry codes: $\mathrm{i}=2-x,-y,-z ; \mathrm{j}=1-x, 1-y,-z$.

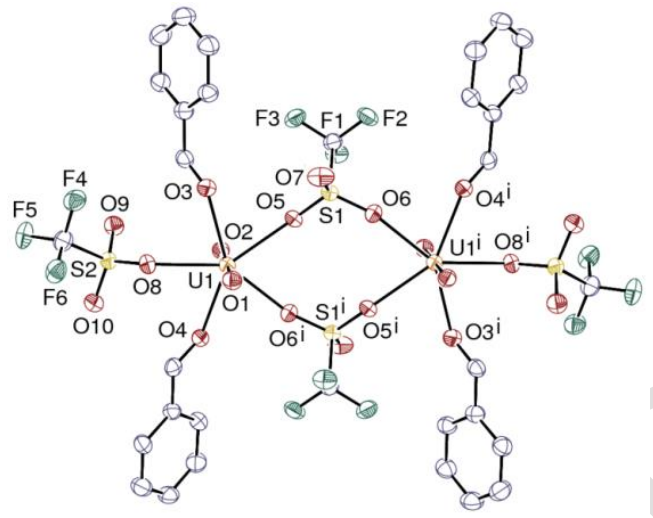

Figure. 2 View of complex 27 with $50 \%$ probability displacement ellipsoids. Hydrogen atoms are omitted for clarity. Symmetry code: $\mathrm{i}=2-x, 2-y, 2-z$.

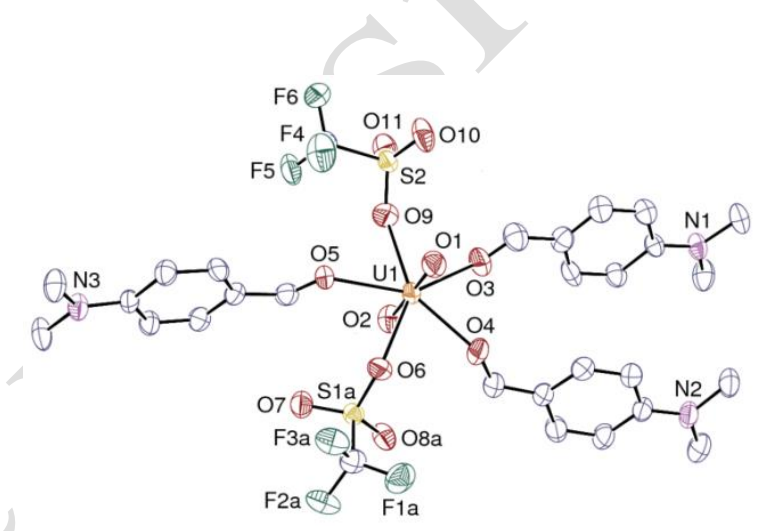

Figure $\mathbf{3}$ View of complex $\mathbf{2 8}$ with $40 \%$ probability displacement ellipsoids. Hydrogen atoms are omitted for clarity.

donors of the aldehyde and triflate ligands, perpendicular to the linear $\mathrm{UO}_{2}$ moiety $\left(\mathrm{O}-\mathrm{U}-\mathrm{O}>178.6^{\circ}\right)$. To our knowledge, 26 is the first $\left[\mathrm{UO}_{2}(\mathrm{OTf})_{2}\right]$ species with a polymeric structure. Connections between the neighboring uranyl entities in $\mathbf{2 6}$ and 27 are ensured by bidentate bridging triflate anions and these compounds are unique uranyl species with $\left(\kappa^{2}-\mu-\mathrm{OTf}\right)$ ligands. The U-O(uranyl), U-O(aldehyde) and U-OTf (bridging bidentate and monodentate) distances in $\mathbf{2 6 , 2 7}$ and 28 are unexceptional, with mean values of 1.743(4) / 1.762(1) /

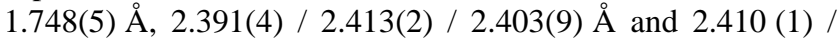
$2.38(2)$ / 2.397(3) $\AA$, respectively. These values can be compared to the mean values of $2.410(1) \AA$ for the monodentate triflates in $\left[\mathrm{UO}_{2}\left(\kappa^{1}-\mathrm{OTf}\right)_{2}(\mathrm{THF})_{3}\right]$ and $2.45(2) \AA$ for the U$\mathrm{O}(\mathrm{ArCH}=\mathrm{O})$ bond length in $\left[\mathrm{UO}_{2}(\mathrm{ALAC})_{2}\left(\mathrm{H}_{2} \mathrm{O}\right)\right]$ and in $\left[\mathrm{UO}_{2}(\mathrm{CSAL})_{2}(\mathrm{DMSO})_{2}\right]$. Finally, the $\mathrm{C}=\mathrm{O}$ bond lengths in $\mathbf{2 8}$ of 1.196(7), 1.235(7) and 1.269(7) $\AA$ can be compared to that in the free aldehyde $15(1.204(2) \AA) .{ }^{44}$ The $\mathrm{N}-\mathrm{C}$ (aromatic) bond lengths are slightly shorter in complex $\mathbf{2 8}$ than in the free aldehyde (1.338(7) (twice) and 1.340(6) ^ vs 1.366(2) $\AA$ ) which seems to confirm the existence of a charge transfer of the ligand $\mathbf{1 5}$ to the metal center.

To gain further information on how the catalytic hydrosilylation proceeds (Eqns. 2 and 4), stoichiometric reactions from isolated uranyl species, labeling experiments, and concomitant addition of a 1:1 mixture of an aldehyde and the derived silylated alcohol were carried out (Eqns 6-10, Scheme 
6). When reacted with a stoichiometric amount of $\mathrm{Et}_{3} \mathrm{SiH}$ ( 1 equiv.) in dichloromethane, complex 27 did not afford any observable intermediate, and only the dibenzyl ether $\mathbf{2 a}$ was produced quantitatively (with respect to $\mathrm{Et}_{3} \mathrm{SiH}$ ) along with siloxane.

Catalytic hydrosilylation of $\mathbf{2}$ and $p$-chlorobenzaldehyde $\mathbf{5}$ with $\mathrm{Et}_{3} \mathrm{SiD}$ and $1 \mathrm{~mol} \% \mathrm{I}$ evidenced, in both cases, the quantitative formation of the corresponding deuterated dibenzylether 2a- $\boldsymbol{d}_{2}$ and 5a- $\boldsymbol{d}_{2}$ formed within $1 \mathrm{~h}$ (Scheme 6, Eqn 6). ${ }^{13} \mathrm{C}\left\{{ }^{1} \mathrm{H}\right\}$ NMR spectra revealed clearly the presence of a single deuterium atom on each methylene moiety $\left(\delta_{\mathrm{CHD}}=71.8 \mathrm{ppm}\right.$ and $\delta_{\mathrm{CHD}}=71.6 \mathrm{ppm}$, respectively with the same ${ }^{3} \mathbf{J}_{\mathrm{C}}$ $\mathrm{D}=21.5 \mathrm{~Hz}$ values). This result confirms a net transfer of the hydride group from silicon to the aldehyde.

In the catalytic formation of ethers (Eqn 2), silylated alcohols were systematically observed in low quantities (1-5\%), whatever the nature of the hydrosilane $\left(\mathrm{Et}_{3} \mathrm{SiH}, \mathrm{PhMe}_{2} \mathrm{SiH}\right.$ and $\mathrm{Ph}_{3} \mathrm{SiH}$ ), before they were fully consumed by the end of the reaction. To evaluate their potential role as intermediates in the formation of ethers, $\mathrm{PhCH}_{2} \mathrm{OSiEt}_{3}$ (2) $\left.\mathbf{b}\right)$ was added to $\mathbf{1}$ (1 $\mathrm{mol} \%$ ) in $\mathrm{CH}_{2} \mathrm{Cl}_{2}$ (Scheme 6, Eqn 7). Although no reaction occurred, addition of 1 equiv. benzaldehyde led to the rapid and incomplete formation of the benzaldehyde dibenzyl acetal (29), in ca. $50 \%$ yield, and $\mathrm{Et}_{3} \mathrm{SiOSiEt}_{3}$ as byproduct (Scheme 6, Eqn 8). Compound 29 was not observed in the catalytic experiments with hydrosilanes but its formation in Eqn 8 was shown unambiguously by NMR ${ }^{45}$ From this mixture, 29 slowly degraded into the corresponding ether $\mathbf{2} \mathbf{a}$ and benzaldehyde 2 within 1 week. To understand this evolution, a labeling experiment with $\mathrm{PhCDO}$ was performed, which unveiled a $\sigma$ bonds metathesis of $\mathbf{2 9}$ catalyzed by the uranium complex. A 1,3-H shift pathway is unlikely, as $\mathrm{PhCHO}$ was absent (Scheme 6, see SI).

As depicted in Eqn 9, replacing the silyl ether $\mathrm{PhCH}_{2} \mathrm{OSiEt}_{3}$ with its sterically congested analogue $\mathrm{PhCH}_{2} \mathrm{OSi}^{\mathrm{i}} \mathrm{Pr}_{3} 2 \mathrm{2c}$ prevented the reaction, and $\mathbf{2 a}$ was not detected after one week at $20{ }^{\circ} \mathrm{C}$. At last, cleavage of $\mathbf{2 9}$ into the ether $\mathbf{2 a}$ is considerably accelerated in presence of the reductant: treatment of $\mathbf{2 9}$ with a mixture of $\mathrm{Et}_{3} \mathrm{SiH}$ (1.2 equiv.) and $\mathbf{1}(1 \mathrm{~mol} \%)$ at $20^{\circ} \mathrm{C}$, led within minutes to the ether $\mathbf{2 a}$ and the silylated alcohol $\mathbf{2 b}$ (Scheme 6, eqn 10). These two important points evidence the key role of acetal intermediates, such as $\mathbf{2 9}$, in the reductive coupling of aldehydes into symmetric ethers.

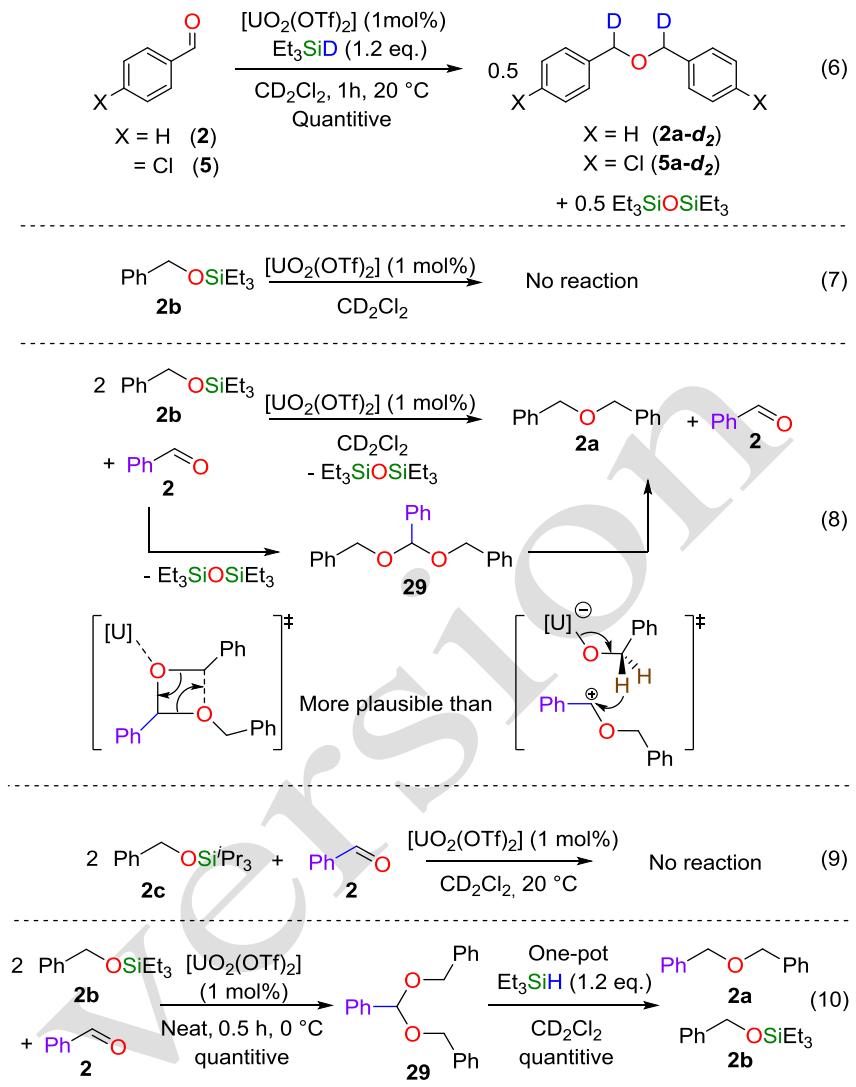

Scheme 6: Reaction of silylated benzyl alcohol $\mathbf{2 b}$ and $\mathbf{2 c}$ with benzaldehyde and deuterium labeling experiments

Based on the above experiments and kinetic results, a plausible mechanism is proposed in Scheme 7, for the uranylcatalyzed hydrosilylation of aldehydes. At the onset, the insoluble polymeric uranyl triflate is coordinated by the aldehydes to yield soluble oligomeric adducts $\left[\mathrm{UO}_{2}(\mathrm{OTf})_{2}(\text { aldehyde })_{n}\right]_{\mathrm{y}}$, likely engaged in equilibria, as reflected in the distinct structures of $\mathbf{2 6}$ and 27. The active uranyl catalyst $\mathbf{A}$ is expected to be unsaturated to enter in the catalytic cycle. The first step of the cycle is the hydrosilylation of the aldehyde RCHO to the silylated alcohol $\mathrm{RCH}_{2} \mathrm{OSiR}_{3}$. The latter reacts with a molecule of aldehyde to give the transient silylated acetal complex C (step 2) which was not detected. Hydrosilylation of the coordinated acetal affords the desired ether $\left(\mathrm{RCH}_{2}\right)_{2} \mathrm{O}$ and the by-product $\left(\mathrm{Et}_{3} \mathrm{Si}\right)_{2} \mathrm{O}$, while catalyst $\mathbf{A}$ is regenerated (steps 3 and 4). Complex $\mathbf{C}$ can also react with $\mathrm{RCH}_{2} \mathrm{OSiR}_{3}$ to provide the acetal analogue of $\mathbf{2 9}$ which, as seen in Eqn 8, is readily transformed into the symmetric ether and the silylated alcohol. This mechanism highlights the key role of acetal intermediates. 


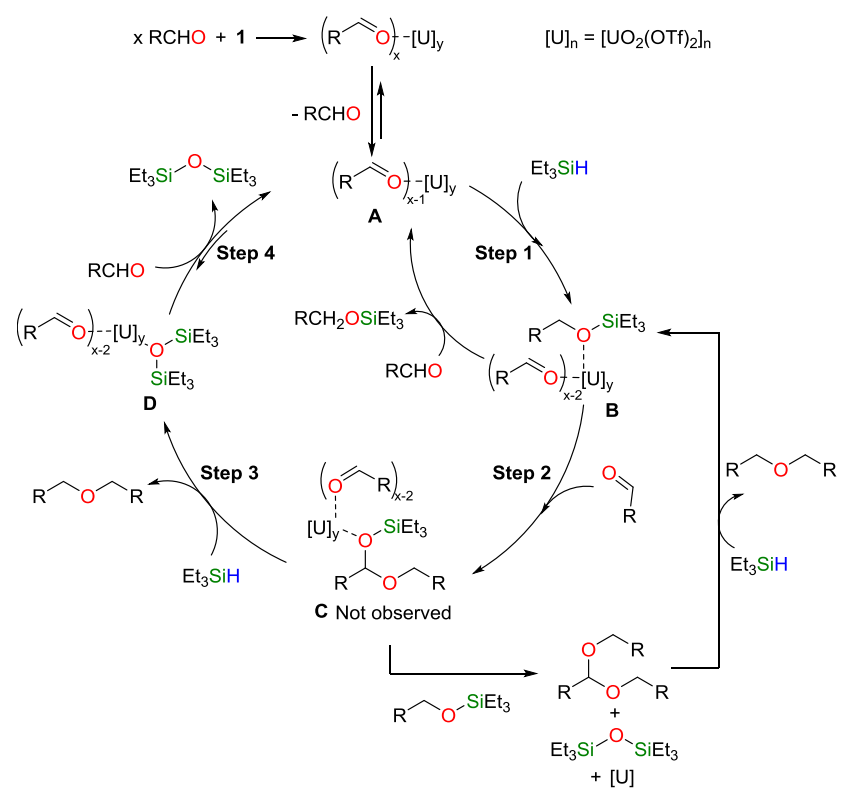

Scheme 7: Plausible mechanism of the uranyl catalyzed reductive coupling of aldehydes into ethers

In conclusion, treatment of uranyl(VI) triflate $\mathbf{1}$ in the presence of hydrosilanes induced the reduction of $\mathrm{C}=\mathrm{O}$ bonds in a large range of aromatic and aliphatic aldehydes. Symmetric ethers and silylated alcohols could be selectively obtained, depending on the nature of the hydrosilane. With $\mathrm{PhMe}_{2} \mathrm{SiH}$, $\mathrm{Ph}_{3} \mathrm{SiH}$ and $\mathrm{Et}_{3} \mathrm{SiH}$, reductive coupling of the aldehydes into the symmetric ethers was observed, while the choice of a more sterically congested hydrosilane, e.g. ${ }^{\mathrm{i}} \mathrm{Pr}_{3} \mathrm{SiH}$, leads to the silylated alcohol $\mathrm{RCH}_{2} \mathrm{OSi}^{\mathrm{i}} \mathrm{Pr}_{3}$ in excellent yield.

This work provides a new and rare example of a catalytic transformation of oxygen-containing molecules with the highly oxophilic actinide ions. Above all, it shows the first use of an actinide complex to carry out catalytic hydrosilylation of $\mathrm{C}=\mathrm{O}$ bonds and clearly evidences that high oxidation state species derived from the ubiquitous uranyl(VI) ion are stable and able to carry out reduction reactions in presence of reducing agents. Despite the uranyl ion contains oxidizing $\mathrm{U}=\mathrm{O}$ bonds, reduction of the $\mathrm{C}=\mathrm{O}$ group and $\mathrm{C}-\mathrm{O}$ bond cleavage are possible without compromising the integrity of the uranyl moiety.

\section{AUTHOR INFORMATION}

\section{Corresponding Author}

* E-mail: jean-claude.berthet@ cea.fr; thibault.cantat@ @ea.fr; Fax: +3316908 6640; Tel: +33169084338

$\dagger$ NIMBE, CEA, CNRS, Université Paris-Saclay, CEA Saclay, 91191 Gif-sur-Yvette, France.

\section{Author Contributions}

The manuscript was written with contributions of all authors. All authors have given approval to the final version of the manuscript.

\section{Funding Sources}

Any funds used to support the research of the manuscript should be placed here (per journal style).

\section{ASSOCIATED CONTENT}

The following files are available free of charge. Supplementary equations, detailed descriptions of experimental methods, kinetic and mechanism studies are provided in the Supporting Information.

\section{Accession Codes}

CCDC 1904787-1904789 contain the supplementary crystallographic data for this paper. These data can be obtained free of charge via www.ccdc.cam.ac.uk/data_request/cif, or by emailing data_request@ccdc.cam.ac.uk, or by contacting The Cambridge Crystallographic Data Centre, 12 Union Road, Cambridge CB2 1EZ, UK; fax: +44 1223336033 .

\section{ACKNOWLEDGMENT}

For financial support of this work, we acknowledge the CEA, CNRS, CHARMMMAT Laboratory of Excellence and the European Research Council (ERC Starting Grant Agreement n.336467). T.C. thanks the Fondation Louis D. - Institut de France for its support. We thank CINES for the allowance of computer time (Project No. c2017086494).

\section{REFERENCES}

1. (a) Liddle, S. T., The Renaissance of Non-Aqueous Uranium Chemistry. Angew. Chem. Int. Ed. 2015, 54, 8604-8641; (b) Liu, H.; Ghatak, T.; Eisen, M. S., Organoactinides in Catalytic Transformations: Scope, Mechanisms and Quo Vadis. Chem. Commun. 2017, 53, 11278-11297; (c) Liu, H.; Kulbitski, K.; Tamm, M.; Eisen, M. S., Organoactinide-Catalyzed Monohydroboration of Carbodiimides. Chemistry 2018, 24, 5738-5742; (d) Arnold, P. L.; Turner, Z. R., Carbon Oxygenate Transformations by Actinide Compounds and Catalysts. Nat. Rev. Chem. 2017, 1, 0002; (e) Mullane, K. C.; Ryu, H.; Cheisson, T.; Grant, L. N.; Park, J. Y.; Manor, B. C.; Carroll, P. J.; Baik, M.-H.; Mindiola, D. J.; Schelter, E. J., C-H Bond Addition Across a Transient Uranium-Nitrido Moiety and Formation of a Parent Uranium Imido Complex. J. Am. Chem. Soc. 2018, 140, 11335-11340; (f) Coughlin, E. J.; Qiao, Y.; Lapsheva, E.; Zeller, M.; Schelter, E. J.; Bart, S. C., Uranyl Functionalization Mediated by Redox-Active Ligands: Generation of $\mathrm{O}-\mathrm{C}$ Bonds via Acylation. $J$. Am. Chem. Soc. 2019, 141, 1016-1026.

2. Fox, A. R.; Bart, S. C.; Meyer, K.; Cummins, C. C., Towards Uranium Catalysts. Nature 2008, 455, 341.

3. Lin, Z.; Marks, T. J., Metal, Bond Energy, and Ancillary Ligand Effects on Actinide-Carbon .Sigma.-Bond Hydrogenolysis. A Kinetic and Mechanistic Study. J. Am. Chem. Soc. 1987, 109, 79797985 .

4. Andrea, T.; Barnea, E.; Eisen, M. S., Organoactinides Promote The Tishchenko Reaction: The Myth of Inactive ActinideAlkoxo Complexes. J Am Chem Soc 2008, 130, 2454-2455.

5. Wobser, S. D.; Marks, T. J., Organothorium-Catalyzed Hydroalkoxylation/Cyclization of Alkynyl Alcohols. Scope, Mechanism, and Ancillary Ligand Effects. Organometallics 2012, 32, 2517-2528.

6. Batrice, R. J.; Kefalidis, C. E.; Maron, L.; Eisen, M. S., Actinide-Catalyzed Intermolecular Addition of Alcohols to Carbodiimides. J Am Chem Soc 2016, 138, 2114-2117.

7. Baker, R. J.; Walshe, A., New Reactivity of the Uranyl Ion: Ring Opening Polymerisation of Epoxides. Chem. Commun. 2012, 48 , 985-987.

8. Walshe, A.; Fang, J.; Maron, L.; Baker, R. J., New Mechanism for the Ring-Opening Polymerization of Lactones? Uranyl Aryloxide-Induced Intermolecular Catalysis. Inorg. Chem. 2013, 52, 9077-9086.

9. Enthaler, S., Straightforward Uranium-Catalyzed Dehydration of Primary Amides to Nitriles. Chemistry 2011, 17, 9316-9319.

10. (a) Fedorov, A.; Toutov, A. A.; Swisher, N. A.; Grubbs, R H., Lewis-Base Silane Activation: From Reductive Cleavage of Aryl 
Ethers to Selective Ortho-Silylation. Chem. Sci. 2013, 4, 1640-1645; (b) Zheng, J.; Chevance, S.; Darcel, C.; Sortais, J.-B., Selective Reduction of Carboxylic Acids to Aldehydes Through Manganese Catalysed Hydrosilylation. Chem. Commun. 2013, 49, 10010-10012; (c) Rauch, M.; Parkin, G., Zinc and Magnesium Catalysts for the Hydrosilylation of Carbon Dioxide. J. Am. Chem. Soc. 2017, 139, $18162-$ 18165.

11. (a) Das, S.; Bobbink, F. D.; Laurenczy, G.; Dyson, P. J., Metal-Free Catalyst for the Chemoselective Methylation of Amines Using Carbon Dioxide as a Carbon Source. Angew Chem Int Edit 2014, 53, 12876-12879; (b) Bobbink, F. D.; Menoud, F.; Dyson, P. J., Synthesis of Methanol and Diols from $\mathrm{CO}_{2}$ via Cyclic Carbonates under Metal-Free, Ambient Pressure, and Solvent-Free Conditions. ACS Sustainable Chem. Eng. 2018, 6, 12119-12123; (c) Lalrempuia, R.; Iglesias, M.; Polo, V.; Sanz Miguel, P. J.; Fernández-Alvarez, F. J.; Pérez-Torrente, J. J.; Oro, L. A., Effective Fixation of $\mathrm{CO}_{2}$ by Iridium-Catalyzed Hydrosilylation. Angew. Chem. Int. Ed. 2012, 51, 12824-12827.

12. (a) Ghatak, T.; Makarov, K.; Fridman, N.; Eisen, M. S., Catalytic Regeneration of a Th-H Bond from a Th-O Bond Through a Mild and Chemoselective Carbonyl Hydroboration. Chem. Commun. 2018, 54, 11001-11004; (b) Mullane, K. C.; Cheisson, T.; NakamaruOgiso, E.; Manor, B. C.; Carroll, P. J.; Schelter, E. J., Reduction of Carbonyl Groups by Uranium(III) and Formation of a Stable Amide Radical Anion. Chem. Eur. J. 2018, 24, 826-837.

13. Liu, H.; Eisen, M. S., Selective Actinide-Catalyzed Tandem Proton-Transfer Esterification of Aldehydes with Alcohols for the Production of Asymmetric Esters. Organometallics 2017, 36 , 1461-1464.

14. (a) Stachowiak, H.; Kaźmierczak, J.; Kuciński, K.; Hreczycho, G., Catalyst-Free and Solvent-Free Hydroboration of Aldehydes. Green Chem. 2018, 20, 1738-1742; (b) Lortie, J. L.; Dudding, T.; Gabidullin, B. M.; Nikonov, G. I., Zinc-Catalyzed Hydrosilylation and Hydroboration of N-Heterocycles. ACS Catal. 2017, 7, 84548459; (c) Obligacion, J. V.; Chirik, P. J., Earth-Abundant Transition Metal Catalysts for Alkene Hydrosilylation and Hydroboration. Nat. Rev. Chem. 2018, 2, 15-34.

15. (a) Cowie, B. E.; Nichol, G. S.; Love, J. B.; Arnold, P. L. Double Uranium Oxo Cations Derived from Uranyl by Borane or Silane Reduction. Chem. Commun. 2018, 54, 3839-3842; (b) Chauvier, C.; Cantat, T., A Viewpoint on Chemical Reductions of CarbonOxygen Bonds in Renewable Feedstocks Including $\mathrm{CO}_{2}$ and Biomass. ACS Catal. 2017, 7, 2107-2115.

16. (a) Feghali, E.; Carrot, G.; Thuéry, P.; Genre, C.; Cantat, T., Convergent Reductive Depolymerization of Wood Lignin to Isolated Phenol Derivatives by Metal-Free Catalytic Hydrosilylation. Energy Environ. Sci. 2015, 8, 2734-2743; (b) Monsigny, L.; Feghali, E.; Berthet, J.-C.; Cantat, T., Efficient Reductive Depolymerization of Hardwood and Softwood Lignins with Brookhart's Iridium(III) Catalyst and Hydrosilanes. Green Chem. 2018, 20, 1981-1986; (c) Adduci, L. L.; McLaughlin, M. P.; Bender, T. A.; Becker, J. J.; Gagne, M. R., Metal-Free Deoxygenation of Carbohydrates. Angew. Chem. Int. Ed. 2014, 53, 1646-1649; (d) McLaughlin, M. P.; Adduci, L. L.; Becker, J. J.; Gagne, M. R., Iridium-Catalyzed Hydrosilylative Reduction of Glucose to Hexane(s). J Am Chem Soc 2013, 135, 1225-1227; (e) Zhang, J.; Chen, Y.; Brook, M. A., Reductive Degradation of Lignin and Model Compounds by Hydrosilanes. ACS Sustainable Chem. Eng. 2014, 2, 1983-1991.

17. (a) Feghali, E.; Cantat, T., Room Temperature Organocatalyzed Reductive Depolymerization of Waste Polyethers, Polyesters, and Polycarbonates. ChemSusChem 2015, 8, 980-984; (b) Monsigny, L.; Berthet, J.-C.; Cantat, T., Depolymerization of Waste Plastics to Monomers and Chemicals Using a Hydrosilylation Strategy Facilitated by Brookhart's Iridium(III) Catalyst. ACS Sustainable Chem. Eng. 2018; (c) Li, A. Y.; Segalla, A.; Li, C.-J.; Moores, A., Mechanochemical Metal-Free Transfer Hydrogenation of Carbonyls Using Polymethylhydrosiloxane as the Hydrogen Source. ACS Sustainable Chem. Eng. 2017, 5, 11752-11760.
18. Pedrick, E. A.; Wu, G.; Kaltsoyannis, N.; Hayton, T. W., Reductive Silylation of a Uranyl Dibenzoylmethanate Complex: an Example of Controlled Uranyl Oxo Ligand Cleavage. Chem. Sci. 2014, 5, 3204-3213.

19. Sassaman, M. B.; Kotian, K. D.; Prakash, G. K. S.; Olah, G. A., General Ether Synthesis under Mild Acid-Free Conditions. Trimethylsilyl Iodide Catalyzed Reductive Coupling of Carbonyl Compounds with Trialkylsilanes to Symmetrical Ethers and Reductive Condensation with Alkoxysilanes to Unsymmetrical Ethers. $J$. Org. Chem. 1987, 52, 4314-4319.

20. Leino, R.; Savela, R., Synthesis of Ethers from Carbonyl Compounds by Reductive Etherification Catalyzed by Iron(III) and Silyl Chloride. Synthesis 2015, 47, 1749-1760.

21. Mineno, T.; Tsukagoshi, R.; Iijima, T.; Watanabe, K.; Miyashita, H.; Yoshimitsu, H., Reductive Coupling Reaction of Aldehydes Using Indium(III) Triflate as the Catalyst. Tetrahedron Lett. 2014, 55, 3765-3767.

22. Bach, P.; Albright, A.; Laali, K. K., Influence of Lewis Acid and Solvent in the Hydrosilylation of Aldehydes and Ketones with $\mathrm{Et}_{3} \mathrm{SiH}$; Tris(pentafluorophenyl)borane $\mathrm{B}\left(\mathrm{C}_{6} \mathrm{~F}_{5}\right)_{3}$ versus Metal Triflates $\left[\mathrm{M}(\mathrm{OTf})_{3} ; \mathrm{M}=\mathrm{Sc}, \mathrm{Bi}, \mathrm{Ga}\right.$, and $\left.\mathrm{Al}\right]$ - Mechanistic Implications. Eur. J. Org. Chem. 2009, 2009, 1961-1966.

23. Zhang, Y.-J.; Dayoub, W.; Chen, G.-R.; Lemaire, M., Copper(II) Triflate-Catalyzed Reduction of Carboxylic Acids to Alcohols and Reductive Etherification of Carbonyl Compounds. Tetrahedron 2012, 68, 7400-7407.

24. Sakai, N.; Nonomura, Y.; Ikeda, R.; Konakahara, T., Zinccatalyzed Reduction of Aldehydes with a Hydrosilane Leading to Symmetric Ethers and Silyl Ethers. Chem. Lett. 2013, 42, 489-491.

25. Baek, J.-Y.; Lee, S.-J.; Han, B.-H., Direct Synthesis of Symmetric Ethers from Carbonyl Compounds Using $\mathrm{SbI}_{3} / \mathrm{PhSiH}_{3} . J$. Korean Chem. Soc. 2004, 48, 220-224.

26. Arias Ugarte, R.; Devarajan, D.; Mushinski, R. M.; Hudnall, T. W., Antimony(v) Cations for the Selective Catalytic Transformation of Aldehydes into Symmetric Ethers, Alpha, BetaUnsaturated Aldehydes, and 1,3,5-Trioxanes. Dalton Trans. 2016, 45 , 11150-11161.

27. (a) Komatsu, N.; Ishida, J.-y.; Suzuki, H., Bismuth Bromide-Catalyzed Reductive Coupling of Carbonyl Compounds and its Application to the Synthesis of Novel Crownophanes. Tetrahedron Lett. 1997, 38, 7219-7222; (b) Gellert, B. A.; Kahlcke, N.; Feurer, M.; Roth, S., Triflic Acid Catalyzed Reductive Coupling Reactions of Carbonyl Compounds with O-, S-, and N-Nucleophiles. Chemistry 2011, 17, 12203-12209; (c) Yadav, J. S.; Subba Reddy, B. V.; Shiva Shankar, K.; Swamy, T., The Reductive Etherification of Carbonyl Compounds using Polymethylhydrosiloxane Activated by Molecular Iodine. Tetrahedron Lett. 2010, 51, 46-48; (d) Zhao, C.; Sojdak, C. A.; Myint, W.; Seidel, D., Reductive Etherification via AnionBinding Catalysis. J. Am. Chem. Soc. 2017, 139, 10224-10227.

28. (a) Kobayashi, S.; Sugiura, M.; Kitagawa, H.; Lam, W. W. L., Rare-Earth Metal Triflates in Organic Synthesis. Chem. Rev. 2002, 102, 2227-2302; (b) Ladziata, V., Recent Applications of Rare-Earth Metal(III) Triflates in Cycloaddition and Cyclization Reactions. Arkivoc 2014, 2014, 307; (c) Ghosh, R.; Maiti, S., Advances in Indium Triflate Catalyzed Organic Syntheses. J. Mol. Catal. A: Chem. 2007, 264, 1-8; (d) Gaspard-Iloughmane, H.; Le Roux, C., Bismuth(III) Triflate in Organic Synthesis. Eur. J. Org. Chem. 2004, 2004, 2517-2532; (e) Deuss, P. J.; Lahive, C. W.; Lancefield, C. S.; Westwood, N. J.; Kamer, P. C.; Barta, K.; de Vries, J. G., Metal Triflates for the Production of Aromatics from Lignin. ChemSusChem 2016, 9, 2974-2981.

29. Hansch, C.; Leo, A.; Taft, R. W., A Survey of Hammett Substituent Constants and Resonance and Field Parameters. Chem. Rev. 1991, 91, 165-195.

30. Ondet, P.; Lemière, G.; Duñach, E., Cyclisations Catalysed by Bismuth(III) Triflate. Eur. J. Org. Chem. 2017, 2017, 761-780.

31. Sorkau, A.; Schwarzer, K.; Wagner, C.; Poetsch, E.; Steinborn, D., Dimerization and Cyclotrimerization of Aldehydes: Ruthenium Catalyzed Formation of Esters, 1,3,5-Trioxanes, and Aldol 
Condensation Products from Aldehydes. J. Mol. Catal. A: Chem. 2004, 224, 105-109.

32. Augé, J.; Gil, R., A Convenient Solvent-Free Preparation of 1,3,5-Trioxanes. Tetrahedron Lett. 2002, 43, 7919-7920.

33. Elamparuthi, E.; Ramesh, E.; Raghunathan, R., $\mathrm{InCl}_{3}$ as an Efficient Catalyst for Cyclotrimerization of Aldehydes: Synthesis of 1,3,5- Trioxane Under Solvent- Free Conditions. Synth. Commun. 2006, 35, 2801-2804.

34. Arias-Ugarte, R.; Wekesa, F. S.; Findlater, M., Selective Aldol Condensation or Cyclotrimerization Reactions Catalyzed by $\mathrm{FeCl}_{3}$. Tetrahedron Lett. 2015, 56, 2406-2411.

35. Hon, Y.-S.; Lee, C.-F., Acetonyltriphenylphosphonium Bromide in Organic Synthesis: a Useful Catalyst in the Cyclotrimerization of Aldehydes. Tetrahedron 2001, 57, 6181-6188.

36. (a) Gomez-Gallego, M.; Sierra, M. A., Kinetic Isotope Effects in the Study of Organometallic Reaction Mechanisms. Chem. Rev. 2011, 111, 4857-4963; (b) Christensen, N. J.; Fristrup, P., Kinetic Isotope Effects (KIE) and Density Functional Theory (DFT): A Match Made in Heaven? Synlett 2015, 26, 508-513.

37. (a) Pagano, J. K.; Dorhout, J. M.; Waterman, R.; Czerwinski, K. R.; Kiplinger, J. L., Phenylsilane as a Safe, Versatile Alternative to Hydrogen for the Synthesis of Actinide hydrides. Chem. Commun. 2015, 51, 17379-17381; (b) Erickson, K. A.; Scott, B. L.; Kiplinger, J. L., $\mathrm{Ca}\left(\mathrm{BH}_{4}\right)_{2}$ as a Simple Tool for the Preparation of Thorium and Uranium Metallocene Borohydride Complexes: First Synthesis and Crystal Structure of $\left(\mathrm{C}_{5} \mathrm{Me}_{5}\right)_{2} \mathrm{Th}\left(\eta^{3}-\mathrm{H}_{3} \mathrm{BH}\right)_{2}$. Inorg. Chem. Commun. 2017, 77, 44-46; (c) Pagano, J. K.; Dorhout, J. M.; Czerwinski, K. R.; Morris, D. E.; Scott, B. L.; Waterman, R.; Kiplinger, J. L., Tuning the Oxidation State, Nuclearity, and Chemistry of Uranium Hydrides with Phenylsilane and Temperature: The Case of the Classic Uranium(III) Hydride Complex $\left[\left(\mathrm{C}_{5} \mathrm{Me}_{5}\right)_{2} \mathrm{U}(\mu-\mathrm{H})\right]_{2}$. Organometallics 2016, 35, 617-620; (d) Altman, A. B.; Brown, A. C.; Rao, G.; Lohrey, T. D.; Britt, R. D.; Maron, L.; Minasian, S. G.; Shuh, D. K.; Arnold, J., Chemical Structure and Bonding in a Thorium(III)-Aluminum Heterobimetallic Complex. Chem. Sci. 2018, 9, 4317-4324.

38. (a) Berthet, J.-C.; Thuéry, P.; Ephritikhine, M., Formation of Uranium(IV) Oxide Clusters from Uranocene $\left[\mathrm{U}\left(\eta^{8}-\mathrm{C}_{8} \mathrm{H}_{8}\right)_{2}\right]$ and Uranyl $\left[\mathrm{UO}_{2} \mathrm{X}_{2}\right]$ Compounds. Inorganic Chemistry 2010, 49, 81738177; (b) Berthet, J. C.; Thuéry, P.; Ephritikhine, M., Unprecedented
Reduction of the Uranyl Ion $\left[\mathrm{UO}_{2}\right]^{2+}$ into a Polyoxo Uranium(IV) Cluster: Synthesis and Crystal Structure of the First F-Element Oxide with a $\mathrm{M}_{6}\left(\mu^{3}-\mathrm{O}\right)_{8}$ Core. Chem. Commun. 2005, 3415-3417.

39. (a) Villiers, C.; Thuéry, P.; Ephritikhine, M., Synthesis and Crystal Structure of $\left[\mathrm{UO}_{2}\left(\mathrm{BH}_{4}\right)_{2}(\mathrm{hmpa})_{2}\right]$, a Novel Uranyl Complex and the First Metal Oxoborohydride. Inorg. Chem. Commun. 2007, 10, 891-893; (b) Ephritikhine, M., Synthesis, Structure, and Reactions of Hydride, Borohydride, and Aluminohydride Compounds of the fElements. Chem. Rev. 1997, 97, 2193-2242.

40. Majumder, I.; Chatterjee, S.; Fischer, R. C.; Neogi, S. K.; Mautner, F. A.; Chattopadhyay, T., Syntheses of $\mathrm{U}_{3} \mathrm{O}_{8}$ Nanoparticles form Four Different Uranyl Complexes: Their Catalytic Performance for Various Alcohol Oxidations. Inorg. Chim. Acta 2017, 462, 112122.

41. Sitran, S.; Fregona, D.; Casellato, U.; Vigato, P. A.; Graziani, R.; Faraglia, G., Synthesis, Characterization and Crystal Structure of 2-dimethylacetal-4-chloro-6-formylphenol and aquabis(2dimethylacetal-4-chloro-6-formylphenolato)dioxouranium(VI). Inorg. Chim. Acta 1986, 121, 103-111.

42. These compounds were always contaminated with a few green crystals of a hexanuclear U(IV) oxide cluster with a central $\left[\mathrm{U}_{6} \mathrm{O}_{4}(\mathrm{OH})_{4}(\mathrm{OTf})_{7}\left(\mathrm{PhCO}_{2}\right)_{5}(\mathrm{PhCHO})_{5}\right]$ core, the crystal structure of which could not be refined in a completely satisfying manner due to considerable disorder..

43. (a) Berthet, J. C.; Nierlich, M.; Ephritikhine, M., Oxygen and Nitrogen Lewis Base Adducts of $\left[\mathrm{UO}_{2}(\mathrm{OTf})_{2}\right]$. Crystal Structures of polypyridine complexes with Out-Of-Plane Uranyl Equatorial Coordination. Dalton Trans. 2004, 2814-2821; (b) Berthet, J. C.; Nierlich, M.; Ephritikhine, M., Isolation of a Uranyl $\left[\mathrm{UO}_{2}\right]^{+}$Species: Crystallographic Comparison of the Dioxouranium(V) and (VI) Compounds $\left[\mathrm{UO}_{2}\left(\mathrm{OPPh}_{3}\right)_{4}\right](\mathrm{OTf})_{\mathrm{n}}(\mathrm{n}=1,2)$. Angew. Chem. Int. Ed. 2003, 42, 1952-1954.

44. Gao, B.; Zhu, J. L., 4-(Dimethyl-amino)benzaldehyde. Acta crystallographica. Section E, Structure reports online 2008, 64, 01182.

45. Tsunoda, T.; Suzuki, M.; Noyori, R., A Facile Procedure for Acetalization Under Aprotic Conditions. Tetrahedron Lett. 1980, $21,1357-1358$. 


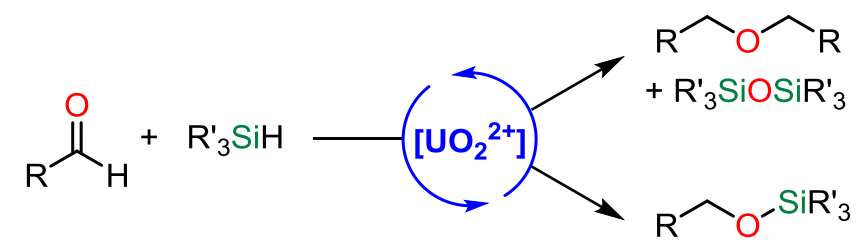

